\title{
In-Storage-Psychrophilic-Anaerobic-Digestion (ISPAD) process. Part I: Model Development and Calibration
}

\author{
Mahsa Madani-Hosseini \\ Dept. of Building, Civil and Environmental Engineering, Concordia University \\ 1455 de Maisonneuve, Montréal, Canada H3G 1M8 \\ E-mail:m.madani84@gmail.com
}

Catherine N. Mulligan

Dept. of Building, Civil and Environmental Engineering, Concordia University

1455 de Maisonneuve, Montréal, Canada H3G 1M8

E-mail: mulligan@civil.concordia.ca

\begin{abstract}
Suzelle Barrington (Corresponding author)
Dept. of Building, Civil and Environmental Engineering, Concordia University 1455 de Maisonneuve, Montréal, Canada H3G 1M8
\end{abstract}

Tel: 0011-450-773-6155 (603)Ｅmail: suzellebarrington@sympatico.ca

Received: August 7, 2015 Accepted: September 1, 2015

doi:10.5296/emsd.v4i2.8116 URL: http://dx.doi.org/10.5296/emsd.v4i2.8116

\begin{abstract}
In-Storage-Psychrophilic-Anaerobic-Digestion (ISPAD) is a treatment system applicable to wastewaters stored for over 100 days, such as livestock wastes and municipal sludge. The ISPAD system differs from conventional reactors by being a sequentially fed batch process operating at a temperature fluctuating with ambient. The objective of this study was to develop a mathematical model to simulate the ISPAD process, verify the value of its microbial kinetics, and to simulate the $\mathrm{pH}$ evolution of its content along with its methane $\left(\mathrm{CH}_{4}\right)$ production. Furthermore, the values of the ISPAD microbial kinetics were compared to that of previous years to track for further acclimation to psychrophilic conditions. Simulation
\end{abstract}


of ISPAD was achieved using the Simulink/Matlab software. The model was calibrated using laboratory data obtained from batch experiments using 7-year-old ISPAD inoculum, and glucose as substrate, and where glucose, VFAs and $\mathrm{pH}$ changes were monitored along with biogas production. The ISPAD model showed good agreement with the experimental data representing the system behaviour between 4 and $35^{\circ} \mathrm{C}$. Although microbial activity at $4{ }^{\circ} \mathrm{C}$ was much slower than that at 18 and $35^{\circ} \mathrm{C}$, it showed acclimation to low temperatures. Furthermore, comparison of microbial kinetic values over 3 years of field ISPAD monitoring demonstrated continued population acclimation, especially for the methanogens.

Keywords: Anaerobic process; Biogas; Modelling; Kinetics parameters; Psychrophilic

\section{Introduction}

Anaerobic digestion (AD) is considered a sustainable treatment for all organic wastes because it produced an energy rich biogas while capturing emissions of methane $\left(\mathrm{CH}_{4}\right)$, a greenhouse gases (Cakir \& Stenstrom, 2005). Nevertheless, AD is generally practiced when subsidized because of the many issues associated with its process. Generally operated under mesophilic conditions, heating is required under cold climatic conditions for a negative energy balance. For many applications, the biogas must be scrubbed to remove corrosive agents and concentrated, besides requiring high compressive pressures to be liquefied for transportation (Kapdi, Vijay, Rajesh, \& Prasad, 2005). Electrical conversion of the biogas is inefficient at 35 to $40 \%$, increasing its energy cost (Biogas, 2011). Investments associated with AD are significant enough to require a large and regular input of organic waste.

In-Storage-Psychrophilic-Anaerobic-Digestion (ISPAD) was developed to eliminate some of the issues associated with AD. Consisting of an airtight cover installed over a storage facility, the ISPAD concept makes use of existing structures to reduce the cost of the reactor. Operating at psychrophilic temperatures fluctuating with that of ambient, ISPAD is a slower process compared to conventional mesophilic systems, compensated by the long storage period of over 100 days (Susan Marguerite King, 2011). Thus, ISPAD is managed as a sequentially fed batch system, where organic waste is regularly added over the storage period, until the system is filled. At that time, the treated waste is removed except for a limited amount left as inoculant for the subsequent batch. The system is operated at ambient temperatures, thus requiring no heating under cold climatic conditions. Furthermore, its low operating temperature and feeding rate make it extremely stable, thus requiring little technical supervision. Because it uses existing storage facilities, ISPAD is a feasible treatment for operations producing small quantities of organic waste. Finally, ISPAD limits ammonia $\left(\mathrm{NH}_{3}\right)$ volatilization and odour emissions of the organic waste while in storage (Susan Marguerite King, 2011).

In-Storage-Psychrophilic-Anaerobic-Digestion (ISPAD) was successfully used to treat swine manures in the Eastern Canada. For a system built in 2004 in the Drummondville area of Eastern Canada, its monitoring demonstrated the effective reduction of swine manure volatile solids and the $63 \%$ released of its total $\mathrm{CH}_{4}$ potential (Susan M. King, Barrington, \& Guiot, 2011). Its microbial population was found to be acclimated to low psychrophilic conditions (Susan M. King et al., 2011), and to be capable of generating biogas even under cold winter 
conditions (Giard, 2011; Nohra, Barrington, Frigon, \& Guiot, 2003). Operated at temperatures under $20^{\circ} \mathrm{C}$, ISPAD biogas was found to contain negligible amounts of $\mathrm{NH}_{3}$, as compared to mesophilic systems (S. King, Schwalb, Giard, Whalen, \& Barrington, 2012).

To further develop the ISPAD system and use its full potential, modelling and simulation are required. For example, the acidification of ISPAD content to a $\mathrm{pH}$ of 6.0 just before emptying for land application would reduce $\mathrm{NH}_{3}$ volatilization and odour emissions from its digestate, while still maintaining a methanogen population capable of inoculating the next batch. Anaerobic digestion (AD) is such a complex process that only mathematical models can predict the outcomes under specific conditions (Donoso-Bravo et al., 2011).

Therefore, the main objectives of this project were to: develop a comprehensive model to predict ISPAD biogas production, substrate consumption, and $\mathrm{pH}$ evolution under its operating temperature ranging from 4 to $35{ }^{\circ} \mathrm{C}$, and; monitor the microbial acclimation of a field ISPAD system established in 2004 and sampled in 2009 and 2012 to inoculate laboratory batch experiments. Several already developed AD models can serve as a base to produce the ISPAD model to concentrate the present research work on including the specificity of the ISPAD operating conditions. The base model must nevertheless be designed to reflect the ISPAD management practices, such as $\mathrm{pH}$ regime and effect of temperature change on microbial kinetics. The present ISPAD model excluded the hydrolysis step as it represents a process as complex as that of AD from the glucose stage.

\section{Selecting the Most Appropriate Base for the ISPAD Model}

In selecting a base to develop the ISPAD model, several existing models where examined, such as the ADM1 (Batstone et al., 2002), the Hill model (D.T Hill, 1982) and the Keshtkar model (Keshtkar, Ghaforian, Abolhamd, \& Meyssami, 2001). The IWA Task Group developed a complex model (ADM1) describing the dynamics of 24 species and 19 bioconversion processes (Batstone et al., 2002). Parameter values are provided for common AD conditons, which simplifies the determination of values for all species and processes. Nevertheless, when applying the ADM1 model to a non standard application, extensive laboratory work must be conducted to establish the kinetics value of all 24 species and the process values of all 19 bioconversions. Considering ISPAD conditions, the ADM1 model neglects some processes and species having a significant impact at low temperatures (Donoso-Bravo et al., 2011) such as the homoacetogenesis step. Homoacetogenesis converts hydrogen and carbon dioxide to acetate and links the two methanogenic pathways of acetate conversion to $\mathrm{CH}_{4}$ by acetoclastic methanogens and carbon dioxide conversion to $\mathrm{CH}_{4}$ by hydrogenotrophic methanogens (O. R. Kotsyurbenko, 2005). The ADM1 model was therefore considered too complex to serve as a model base.

Working especially with dairy manures, D.T Hill (1982) developed an AD model which included the homoacetogensis step and operated under mesophilic and thermophilic temperatures. Tested at low temperatures for the treatment of swine manure, the model could not reasonably predict the degradation process. The Hill (1982) model failed to work under high organic loads offered by high degradable swine manure producing acids and $\mathrm{NH}_{3}$ in much larger quantities as compared to dairy manures (D. T. Hill, Taylor, \& Grift, 2001). 


\section{Mll Macrothink}

The psychrophilic AD model developed by Massé and Droste (2000) applies to a sequencing batch reactor, whereas ISPAD is a sequentially fed batch system. Furthermore, homoacetogenesis is not considered. In modelling low temperature AD systems, V. A. Vavilin, Lokshina, Rytov, Kotsyurbenko, and Nozhevnikova (1998) demonstrated that the homoacetogenesis step was important. Also, V. A. Vavilin et al. (1998) considered only pH inhibition while $\mathrm{NH}_{3}$ and VFA inhibition is also important (Angelidaki, Ellegaard, \& Ahring, 1993).

Developed for the batch treatment of livestock manures, the Keshtkar et al. (2001) model considers a limited number of parameters to be defined experimentally, while still considering the main $\mathrm{AD}$ inhibitors such as $\mathrm{pH}, \mathrm{NH}_{3}$, and acetate. The model is also capable of predicting the $\mathrm{pH}$ regime, an element essential to the modelling of the ISPAD process. Because of these capabilities, the Keshtkar et al. (2001) model was used as a base for the development of the ISPAD model.

Nevertheless, the Keshtkar et al. (2001) model must be modified to properly predict the ISPAD process. First of all, it lumps the two main groups of methanogens, acetoclastic and hydrogenotrophic, whereas for ISPAD simulation, these two main groups must be differentiated. They respond differently to environmental conditions and differ in terms of substrate consumption, namely acetate and carbon dioxide, respectively. The Keshtkar et al. (2001) model also predicts $\mathrm{CH}_{4}$ production at mesophilic temperature without considering the homoacetogenesis step, which is the conversion of carbon dioxide to acetate. This step is dominant at low temperatures and must be included in the ISPAD model to correctly predict $\mathrm{CH}_{4}$ production. Whereas the Keshtkar et al. (2001) model only considers one operating temperature, the ISPAD model must include a temperature function for the maximum microbial growth rate, $\mu_{\max }$, and the acid/base dissociation constant $\left(K_{a}\right)$. Such temperature effect can be defined by the Arrhenius and Square Root equations (Madani-Hosseini, Barrington, \& Mulligan, 2014).

Finally, the ISPAD model must be tested using its specific kinetic values obtained experimentally. The ISPAD system depends on microbial acclimation to low temperatures and low organic loads diluted over time as the system fills up. The developed ISPAD model will be initialized using kinetic values estimated for each AD group from 2009 ISPAD samples tested in the laboratory using substrate activity tests, and then fitted by Madani-Hosseini et al. (2014) to the Monod equation. Such initial kinetic values facilitate the fitting process using experimental data with less chance of being trapped in local minima. Furthermore, the 2009 kinetic values were also compared with those obtained in this study from 2012 ISPAD samples to evaluate the evolution of the ISPAD microbial acclimation over 3 years of operation.

\section{Materials and Methods}

\subsection{Model Description}

In this study, $3 \mathrm{AD}$ steps were considered: acidogenesis, acetogenesis and methanogenesis 


\section{Macrothink}

(Figure 1). The hydrolysis step was not considered, because the simulation of its degradation process can be quite elaborate for complex organic molecules as found in wastewaters. Thus, the ISPAD model was run assuming that the hydrolysis process had degraded carbohydrates and amino acids into glucose and ammoniacal nitrogen. The production of ammoniacal nitrogen from the fed wastewaters was modeled through Eq. 12 presented later on. In the first step called acidogenesis, glucose is degraded into simple compounds such as VFAs and $\mathrm{CO}_{2}$. The most important VFAs, in terms of biogas production, are propionic, butyric and acetic acids. The consumption of glucose and the growth of acidogens are assumed to obey Monod-type kinetics considering $\mathrm{pH}$ inhibition of acidogens $\left(F_{A}(p H)\right)$ (Table 1).

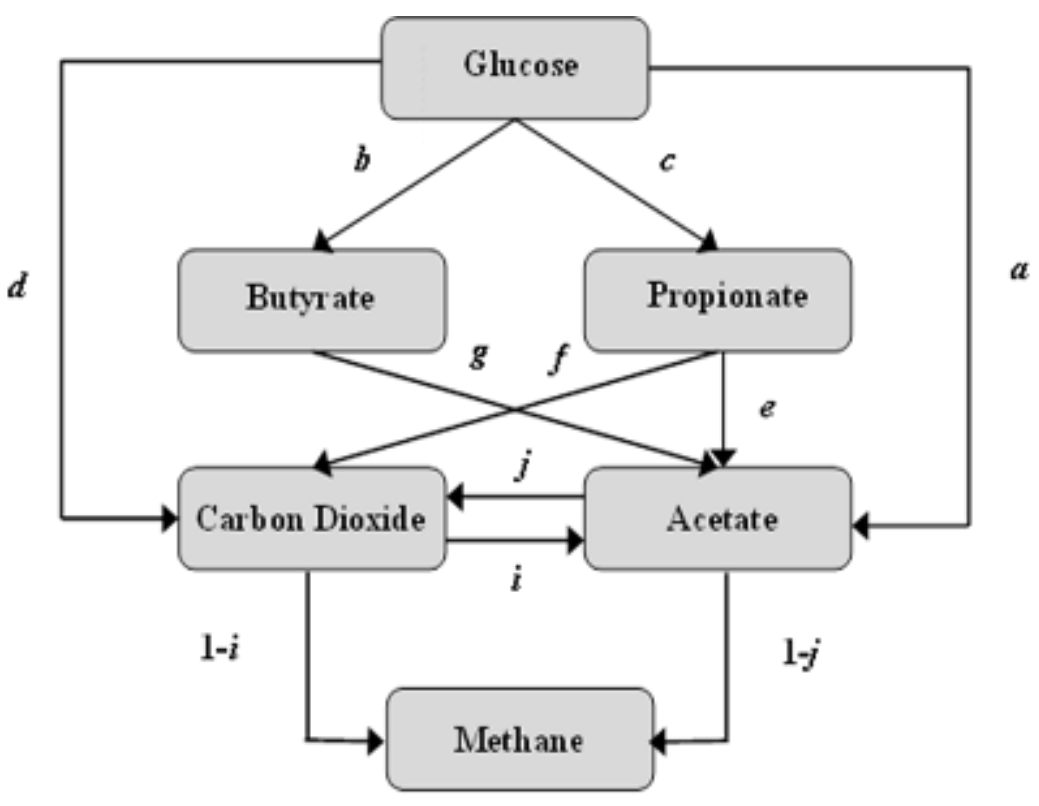

Figure 1. Scheme of carbon substrate conversion in anaerobic digestion, neglecting the biomass production. Letters indicate conversion factors used in the model, shown in Table 6 .

The effect of $\mathrm{pH}$ inhibition $(F(p H))$ on the growth rate was described by a Michaelis $\mathrm{pH}$ function, normalized to give a value of 1.0 as the center value (Angelidaki et al., 1993):

$$
F(p H)=\frac{1+2 \times 10^{0.5\left(p k_{1}-p k_{h}\right)}}{1+10^{\left(p H-p k_{h}\right)}+10^{\left(p k_{1}-p H\right)}}
$$

here the coefficient $p K_{1}$ and $p K_{h}$ are the lower and upper $\mathrm{pH}$ drop-off value with the microbial growth rate equal to $50 \%$ of the uninhibited rate. Below $p K_{1}$ and above $p K_{h}$, the growth rate is almost zero. 


\section{Macrothink}

Table 1. Kinetic equations used in the model

\begin{tabular}{|c|c|c|}
\hline Process & Microbial growth rate & Microbial mass balance \\
\hline Acidogenesis & $\mu_{A}=\mu_{\max A} \frac{s_{g \text { Iu }}}{K_{\text {sglu }}+s_{g \text { Iu }}} \times F_{A}(p H)$ & $\frac{d x_{A}}{d t}=\left(\mu_{A}-k_{d A}\right) X_{A}$ \\
\hline $\begin{array}{l}\text { Butyrate } \\
\text { degrading } \\
\text { acetogenesis }\end{array}$ & $\mu_{A B}=\mu_{\max A B} \frac{s_{b u t}}{K_{s b u t}+s_{\text {but }}} \times \frac{K_{\text {ibut }}}{K_{\text {ibut }}+s_{a c}} \times F_{A B}(p H)$ & $\frac{d X_{A B}}{d t}=\left(\mu_{A B}-k_{d A B}\right) X_{A B}$ \\
\hline $\begin{array}{l}\text { Propionate } \\
\text { degrading } \\
\text { acetogenesis }\end{array}$ & $\mu_{A P}=\mu_{\max A P} \frac{S_{p r}}{K_{s p r}+S_{p r}} \times \frac{K_{i p r}}{K_{i p r}^{i}+S_{a c}} \times F_{A P}(p H)$ & $\frac{d X_{A p}}{d t}=\left(\mu_{A p}-k_{d A p}\right) X_{A p}$ \\
\hline Homoacetogenesis & $\mu_{\mathrm{Hom}}=\mu_{\operatorname{maxHom}} \frac{s_{\mathrm{CO}_{2}}}{K_{s \mathrm{CO}_{2}-\mathrm{Hom}}+s_{\mathrm{CO}_{\mathrm{z}}}} \times F_{\mathrm{Hom}}(p H)$ & $\frac{d X_{H o m}}{d t}=\left(\mu_{H o m}-k_{d H o m}\right) X_{H o m}$ \\
\hline $\begin{array}{l}\text { Acetoclastics } \\
\text { Methanogenesis }\end{array}$ & $\mu_{M}=\mu_{\max M} \frac{s_{a c}}{K_{a a c}+s_{a c}} \times \frac{K_{\text {iam }}}{K_{\text {iam }}+s_{a m}} \times F_{M}(p H)$ & $\frac{d X_{M}}{d t}=\left(\mu_{M}-k_{d M}\right) X_{M}$ \\
\hline $\begin{array}{l}\text { Hydrogenotrophic } \\
\text { Methanogenesis }\end{array}$ & $\mu_{M H}=\mu_{\operatorname{maxMH}} \frac{s_{\mathrm{CO}_{2}}}{K_{\mathrm{sCO}}-\mathrm{MH}_{2}+s_{\mathrm{CO}_{2}}} \times F_{M H}(p H)$ & $\frac{d x_{M H}}{d t}=\left(\mu_{M H}-k_{d M H}\right) X_{M H}$ \\
\hline
\end{tabular}

Inhibition by $\mathrm{pH}$ was considered for other degradation steps including acetogenesis and methanogens. The coefficients $p K_{1}$ and $p K_{h}$ differ depending on the microbial group (Table 2).

Table 2. $p K_{1}$ and $p K_{h}$ values used in the model (Keshtkar et al., 2001)

\begin{tabular}{|l|l|l|}
\hline Parameter & \multicolumn{1}{|c|}{ Type of microorganism } & Value \\
\hline$p K_{1 A}$ & Acidogen & 5.0 \\
\hline$p K_{h A}$ & Acidogen & 8.0 \\
\hline$p K_{1 A P}$ & Propionate degrading acetogen & 6.0 \\
\hline$p K_{h A P}$ & Propionate degrading acetogen & 8.5 \\
\hline$p K_{1 A B}$ & Butyrate degrading acetogen & 6.0 \\
\hline$p K_{h A B}$ & Butyrate degrading acetogen & 8.5 \\
\hline$p K_{1 M A}$ & Acetoclastic methanogens & 6.0 \\
\hline
\end{tabular}




\begin{tabular}{|l|l|l|}
\hline$p K_{\text {hMA }}$ & Acetoclastic methanogens & 8.5 \\
\hline$p K_{1 M H}$ & Hydrogenotrophic methanogens & 6.0 \\
\hline$p K_{\text {hMH }}$ & Hydrogenotrophic methanogens & 8.5 \\
\hline$p K_{1 \mathrm{Hom}}$ & Homoacetogen & 6.0 \\
\hline$p K_{\text {hHom }}$ & Homoacetogen & 8.5 \\
\hline
\end{tabular}

Acetogenesis is the second step conducted by acetogenic bacteria, whereby low molecular weight VFAs are converted into acetate and $\mathrm{CO}_{2}$. In addition, $\mathrm{CO}_{2}$ used by other acetogenic bacteria, homoacetogens, are converted into acetate. Besides using Monod-type kinetics to simulate the consumption of propionate and butyrate, non-competitive inhibition functions were introduced in the model for acetate inhibition (Table 1).

The third and final step producing $\mathrm{CH}_{4}$, is carried out by acetoclastic methanogens decarboxylating acetate, and hydrogenotrophic methanogens using $\mathrm{H}_{2}$ to reduce $\mathrm{CO}_{2}$ (Figure 1). Ammonia inhibition was considered for acetoclastic methanogens (Table 1), as $\mathrm{NH}_{3}$ is expected to play an important role in AD inhibition (Batstone et al., 2002; D. T. Hill \& Barth, 1977).

\subsection{Mass Balance and Model Equation}

The ISPAD model is based on a mass balance analysis of substrate, carbon and the biomass for each microbial group of the AD consortium. The ISPAD system is an airtight tank receiving a specific volume, $V$, of wastewater at a regular interval of time, $t_{r}$. Once full, the ISPAD tank is emptied except for a residual volume used as inoculum for the refilling process, which is initiated immediately thereafter.

Thus, at any time $t_{\bar{i}}$, being a multiple of $t_{r}$, the ISPAD tank holds a volume $V_{i}$ with: a microbial population for each group of the AD consortium of $X_{i j}$, where $i$ refers to the time step and $j$ refers to the microbial group; for each microbial group of the AD consortium also, the substrate concentration is $S_{i j}$. If at this time $t_{i}$, a known volume of fresh wastewater is added, the microbial population of each group becomes diluted by the fresh wastewater with very little addition of $\mathrm{AD}$ microbes: 


$$
X_{(i+1) j}=\frac{V_{i} \times X_{i j}}{\left(V+V_{i}\right)}
$$

This volume of wastewater also increases the substrate concentration for each microbial group of the $\mathrm{AD}$ consortium, as each microbial group breaks down its substrate, to produce substrate for the next $\mathrm{AD}$ group within the chain of reactions:

$$
S_{(i+1) j}=\frac{V_{i} \times S_{i j}+V \times S_{0}}{\left(V+V_{i}\right)}
$$

where $S_{0}$ is the substrate concentration of the volume of fresh wastewater added to the ISPAD system.

Once the ISPAD microbial populations and substrate concentrations are readjusted according to the volume of fresh wastewater received, then the ISPAD model can compute for each time sequence, changes in parameters, such as microbial population growth, substrate consumption, VFA production, $\mathrm{pH}$ of the digestate and finally $\mathrm{CH}_{4}$ production over time $t_{r}$. The Monod equation is used for this purpose, assuming a mass balance in terms of microbial population, substrate and carbon. Since there is neither inflow nor outflow, then, the following simple equations apply:

$$
\begin{gathered}
\frac{d X}{d t}=\left(\mu-K_{d}\right) X \\
\frac{d S}{d t}=-\frac{1}{Y} \frac{d X}{d t}
\end{gathered}
$$

Because the ISPAD model considers the inhibition effect of $\mathrm{pH}$, acetate and $\mathrm{NH}_{3}$, the growth rate, $\mu$, is described in Table 1 .

The ISPAD model therefore simulates batch processes occurring sequentially: each sequential step is initiated by the addition of a known volume $V$ at every time interval $t_{r}$. The digestion period for each step is also $t_{r}$.

Accordingly, Eq. (4-5) can be translated for each substrate based on carbon balance: 


$$
\begin{aligned}
& \frac{d s_{g l u}-C}{d t}=\frac{1}{Y_{A}} \frac{d x_{A}}{d t} \\
& \frac{d s_{b u t-C}}{d t}=b\left(\frac{1}{Y_{A}} \frac{d x_{A}}{d t}\right)-\left(\frac{1}{Y_{A B}} \frac{d x_{A B}}{d t}\right) \\
& \frac{d s_{p r}-C}{d t}=C\left(\frac{1}{Y_{A}} \frac{d x_{A}}{d t}\right)-\left(\frac{1}{Y_{A P}} \frac{d x_{A P}}{d t}\right) \\
& \frac{d s_{C O_{2}}-C}{d t}=d\left(\frac{1}{Y_{A}} \frac{d x_{A}}{d t}\right)+f\left(\frac{1}{Y_{A P}} \frac{d X_{A P}}{d t}\right)+j\left(\frac{1}{Y_{M}} \frac{d X_{M}}{d t}\right)-\left[i\left(\frac{1}{Y_{H o m}} \frac{d X_{H o m}}{d t}\right)+1-i\left(\frac{1}{Y_{M H}} \frac{d X_{M H}}{d t}\right)\right] \\
& \frac{d s_{a c-C}}{d t}=a\left(\frac{1}{Y_{A}} \frac{d x_{A}}{d t}\right)+e\left(\frac{1}{Y_{A P}} \frac{d x_{A P}}{d t}\right)+g\left(\frac{1}{Y_{A B}} \frac{d x_{A B}}{d t}\right)+i\left(\frac{1}{Y_{H o m}} \frac{d X_{H o m}}{d t}\right)-\left[j\left(\frac{1}{Y_{M}} \frac{d X_{M}}{d t}\right)+1-\right. \\
& \left.j\left(\frac{1}{Y_{M}} \frac{d X_{M}}{d t}\right)\right] \\
& \frac{d s_{C H_{4}-C}}{d t}=1-i\left(\frac{1}{Y_{M H}} \frac{d X_{M H}}{d t}\right)+1-j\left(\frac{1}{Y_{M}} \frac{d X_{M}}{d t}\right) \\
& \frac{d S_{N H_{\Xi}}}{d t}=K S_{O N}-\left(\mu_{A} X_{A}+\mu_{A P} X_{A P}+\mu_{A B} X_{A B}+\mu_{M} X_{M}+\mu_{M H} X_{M H}+\mu_{H o m} X_{H o m}\right)
\end{aligned}
$$

Eq. 12 was added to the ISPAD model to simulate the ammoniacal nitrogen generated from the hydrolysis of the wastewaters. Thus, Eq. 12 predicts the release ammonium from organic nitrogen $\left(S_{O N}\right)$ at a rate constant $K$, because such ammoniacal nitrogen can inhibit AD when produced in excess of what the microbial groups can consume.

\subsection{The pH Prediction}

In $\mathrm{AD}, \mathrm{pH}$ prediction is important because it affects microbial growth and total $\mathrm{NH}_{3}$ concentration (Chen, Cheng, \& Creamer, 2008). Furthermore, $\mathrm{pH}$ is one of the most important parameters affecting $\mathrm{NH}_{3}$ volatilization besides temperature. Therefore, the ISPAD model needs to predict the $\mathrm{pH}$ of its content for further investigation on controlling of $\mathrm{NH}_{3}$ volatilization. In $\mathrm{AD}$ systems, $\mathrm{pH}$ is mainly controlled by the interaction of the carbon dioxide/bicarbonate buffer system with bases such as $\mathrm{NH}_{3}$, and acids such as VFAs mainly propionate, butyrate and acetate. The ionic balance between the following elements is 
generally used to compute the $\mathrm{pH}$ of a system: $\mathrm{CO}_{2}, \mathrm{NH}_{3}$, VFAs (acetate, ac ${ }^{-}$, propionate, $\mathrm{pr}^{-}$, and butyrate, but $\left.{ }^{-}\right)$, and cations $\left(\mathrm{C}^{+}\right)$and anions $\left(\mathrm{A}^{-}\right)$. The following equation is used for that purpose:

$$
\left[\mathrm{H}^{+}\right]+\left[\mathrm{NH}_{4}^{+}\right]+\left[\mathrm{C}^{+}\right]=\left[\mathrm{OH}^{-}\right]+\left[\mathrm{HCO}_{3}^{-}\right]+2\left[\mathrm{CO}_{3}^{2-}\right]+\left[\mathrm{ac}^{-}\right]+\left[\mathrm{pr}^{-}\right]+\left[\mathrm{but}^{-}\right]+\left[\mathrm{A}^{-}\right]
$$

To simulate $\mathrm{pH}$ variation with time, the ionic charge balance (Eq. 13) needs to be iteratively solved. Only the sum of the concentration of anions $\left(A^{-}\right)$and cations $\left(C^{+}\right)$is assumed to be independent of time and their initial values were used.

The concentrations of ionic compounds can be obtained according to Eq. (14) to (20).

$$
\begin{aligned}
& \mathrm{CO}_{2}+\mathrm{H}_{2} \mathrm{O} \leftrightarrow \mathrm{HCO}_{3}^{-}+\mathrm{H}^{+} \\
& K_{a 1}=\frac{\left[\mathrm{HCO}_{\mathrm{g}}^{-}\right]\left[\mathrm{H}^{+}\right]}{\left[\mathrm{CO}_{2}\right]} \\
& \mathrm{HCO}_{3}^{-} \leftrightarrow \mathrm{CO}_{3}^{2-}+\mathrm{H}^{+} \\
& K_{a 2}=\frac{\left[\mathrm{CO}_{\mathrm{a}}^{2-}\right]\left[\mathrm{H}^{+}\right]}{\left[\mathrm{HCO}_{\mathrm{g}}^{-}\right]} \\
& H A C \leftrightarrow A C^{-}+H^{+} \\
& K_{a 3}=\frac{\left[A C^{-}\right]\left[H^{+}\right]}{[H A C]} \\
& \mathrm{HPr} \leftrightarrow \mathrm{Pr}^{-}+\mathrm{H}^{+} \\
& K_{a 4}=\frac{\left[p_{r}^{-}\right]\left[H^{+}\right]}{[H P r]} \\
& \text { HBut } \leftrightarrow B u t^{-}+H^{+} \\
& K_{a 5}=\frac{\left[B u t^{-}\right]\left[H^{+}\right]}{[H B u t]} \\
& \mathrm{NH}_{4}^{+} \leftrightarrow \mathrm{NH}_{3}+\mathrm{H}^{+} \\
& K_{a 6}=\frac{\left[N H_{8}\right]\left[H^{+}\right]}{\left[\mathrm{NH}_{4}^{+}\right]} \\
& \mathrm{H}_{2} \mathrm{O} \leftrightarrow \mathrm{OH}^{-}+\mathrm{H}^{+} \\
& K_{w}=\left[\mathrm{OH}^{-}\right]\left[\mathrm{H}^{+}\right]
\end{aligned}
$$

The dissociation constants $\left(K_{a}\right)$ presented in the third column of Table 3 are theoretical values 
found for pure solutions.

Table 3. Dissociation coefficients at 35,18 , and $4{ }^{\circ} \mathrm{C}$

\begin{tabular}{|c|c|c|c|c|c|}
\hline Parameter & Units & $\begin{array}{c}\text { Reported } \\
\text { value }^{1}\end{array}$ & $\begin{array}{l}\text { Fitted value } \\
35{ }^{0} \mathrm{C}\end{array}$ & $\begin{array}{c}\text { Temperature } \\
\text { corrected fitted } \\
\text { value } 18{ }^{0} \mathrm{C}\end{array}$ & $\begin{array}{c}\text { Temperature } \\
\text { corrected fitted } \\
\text { value } 4{ }^{0} \mathrm{C}\end{array}$ \\
\hline$K_{a 1}$ & $\mathrm{mmol} / \mathrm{L}$ & $4.909 \times 10^{-4}$ & $4.909 \times 10^{-4}$ & $3.69 \times 10^{-11}$ & $1.59 \times 10^{-62}$ \\
\hline$K_{a 2}$ & $\mathrm{mmol} / \mathrm{L}$ & $5.623 \times 10^{-8}$ & $3.82 \times 10^{-7}$ & $1.95 \times 10^{-14}$ & $5.08 \times 10^{-67}$ \\
\hline$K_{a 3}$ & $\mathrm{mmol} / \mathrm{L}$ & $1.73 \times 10^{-2}$ & $1.73 \times 10^{-2}$ & $2.03 \times 10^{-9}$ & $2.12 \times 10^{-59}$ \\
\hline$K_{a 4}$ & $\mathrm{mmol} / \mathrm{L}$ & $1.445 \times 10^{-2}$ & $1.5 \times 10^{-3}$ & $2.69 \times 10^{-11}$ & $6.01 \times 10^{-59}$ \\
\hline$K_{a 5}$ & $\mathrm{mmol} / \mathrm{L}$ & $1.445 \times 10^{-2}$ & $1.5 \times 10^{-3}$ & $2.69 \times 10^{-11}$ & $6.01 \times 10^{-59}$ \\
\hline$K_{a 6}$ & $\mathrm{mmol} / \mathrm{L}$ & $1.567 \times 10^{-6}$ & $1.567 \times 10^{-6}$ & $1.527 \times 10^{-14}$ & $2.55 \times 10^{-72}$ \\
\hline$K_{w}$ & $\mathrm{mmol} / \mathrm{L}$ & $2.065 \times 10^{-11}$ & $2.065 \times 10^{-10}$ & $1.039 \times 10^{-11}$ & $5.5 \times 10^{-12}$ \\
\hline
\end{tabular}

Dissociation constants at $35{ }^{0} \mathrm{C}$ (Dean, 1992). $K_{a 1}, K_{a 2}, K_{a 3}, K_{a 4}, K_{a 5}, K_{a 6}$, and $K_{w}$ are first dissociation constant for carbonic acid, second dissociation constant for carbonic acid, dissociation constant for acetic acid, propionic acid, butyric acid, ammonia, and water, respectively.

In wastewaters, $K_{a}$ can change because of the interaction of especially dissolved carbon with other active species (Liu, Giard, \& Barrington, 2013). Accordingly, $K_{a}$ values where found by a process of optimization using $\mathrm{pH}$ data obtained from ISPAD inoculum fed glucose at $35{ }^{\circ} \mathrm{C}$. As ISPAD operates at ambient temperatures, and temperature affects $K_{a}$, a temperature function was included for $K_{a}$ determination. Therefore, the $K_{a}$ values were optimized for $35{ }^{\circ} \mathrm{C}$ conditions and then computed for 18 and $4{ }^{\circ} \mathrm{C}$ based on the Van't Hoff 
Equation:

$$
\ln \left(\frac{K_{a x}}{K_{a 1}}\right)=\frac{-\Delta H}{R^{*}}\left(\frac{1}{T_{2}}-\frac{1}{T_{1}}\right)
$$

where $K_{a 1}$ is the dissociation constants at $T_{1}(\mathrm{~K}), K_{a 2}$ is dissociation constant at $T_{2}(\mathrm{~K})$, $\Delta H$ is enthalpy of the reaction ( $\mathrm{J} / \mathrm{mole})$, and $R^{*}$ is universal gas constant $(8.314 \mathrm{~J} / \mathrm{mole} \mathrm{K})$.

\subsection{Temperature effects on $\mu_{\max }$}

The temperature effect on $\mu_{\max }$, is commonly described by the Arrhenius and the Square Root Equations. According to the Arrhenius equation (Eq. 22), the reaction rate roughly doubles for a temperature increase of $10^{\circ} \mathrm{C}$ (Loehr, 1984):

$$
\mu_{\max }=A e^{\frac{-E a}{R^{*} T}}
$$

where $A$ is a constant, $R^{*}$ is the universal gas constant $(0.008314 \mathrm{~kJ} / \mathrm{mol} K), T$ is temperature $(K)$ and $\mathrm{E}_{\mathrm{a}}$ is the activation energy $(\mathrm{kJ} / \mathrm{mol})$.

The Square Root equation describes a less than optimum temperature adaptation of bacterial growth in pure cultures:

$$
\sqrt{\mu_{\max }}=b\left(T-T_{\min }\right)
$$

where $T_{\min }$ is the apparent minimum temperature for growth $(K)$, and $b$ is the regression coefficient.

Madani-Hosseini et al. (Madani-Hosseini et al., 2014) optimized the values of $\mathrm{E}_{\mathrm{a}}$ and $T_{\min }$ for ISPAD population groups to compare the prediction accuracy of both the Arrhenius and the Square Root equations, describing the relationship between temperature and $\mu_{\max }$. The results showed that the Square Root equation predicted temperature dependency for both 
acidogens and propionate degrading acetogens, while the Arrhenius equation better predicted temperature effect for methanogens and butyrate degrading acetogens. The ISPAD model therefore incorporates both of these equations accordingly.

\subsection{Model Assumptions}

Anaerobic digestion is a complex process which can be simplified through assumptions. Thus, the $\mathrm{AD}$ process of the ISPAD system was simplified using the following assumptions:

- The ISPAD model only focuses on carbohydrate (glucose) degradation.

- The $\mathrm{H}_{2}$ production was not considered in the model, since the ISPAD model is based on carbon balance.

- To calculate the $\mathrm{pH}$, all acid/base pairs were considered in equilibrium.

- For each step, the reactor is operated at constant volume.

- Since the most important VFAs, in terms of biogas production, are propionic, butyric and acetic acids, the other VFAs such as valerate were not considered.

- Biogas contains $\mathrm{CH}_{4}$ and $\mathrm{CO}_{2}$, where $\mathrm{CH}_{4}$ has low solubility in liquid phase.

- The reactor behaves like a perfectly mixed tank, and the biomass and substrate are uniformly distributed within the reactor.

\subsection{Model Calibration and Kinetic Parameters Estimation}

For the calibration of the model, batch experiments were conducted in the laboratory using inoculum obtained from a 7-year-old field ISPAD in the spring of 2012. These batch experiments produced curves for glucose degradation and VFAs and $\mathrm{CH}_{4}$ production over time at temperatures of 4,18 , and $35{ }^{\circ} \mathrm{C}$. All samples were duplicated and the results averaged. The inoculum consisting of $100 \mathrm{ml}$ of ISPAD content $(7.2 \mathrm{gVS} / \mathrm{L})$ was placed in $250 \mathrm{ml}$ bottles containing $50 \mathrm{ml}$ glucose at a concentration of $1000 \mathrm{mg} / \mathrm{L}$. The total volume of liquid in each $250 \mathrm{ml}$ bottle was therefore $150 \mathrm{ml}$ with a VS concentration of $4.8 \mathrm{~g} / \mathrm{L}$ and a glucose concentration of $333 \mathrm{mg} / \mathrm{L}$. Bottles were capped, sealed and flushed with $\mathrm{N}_{2}$ gas to establish anaerobic conditions, before starting the AD process and monitoring glucose and VFA concentrations, and $\mathrm{CH}_{4}$ production. The mixture was shaken by hand once a day. The system was run at 3 controlled temperatures of 4,18 , and $35^{\circ} \mathrm{C}$ : for 18 and $35^{\circ} \mathrm{C}$, the bottles were incubated, while for $4{ }^{\circ} \mathrm{C}$, the bottles were refrigerated. For each temperature, duplicate control bottles were prepared with ISPAD inoculum and water instead of glucose. Some 15 bottles were prepared for each temperature treatment, to destroy a bottle at every sampling even. Samples of $2 \mathrm{ml}$ were regularly withdrawn from the bottle headspace for gas production analysis using a gas chromatograph while gas production was monitored until gas production ceased, using a water displacement apparatus. Also, $2 \mathrm{ml}$ liquid samples were removed from each bottle at specified time intervals to monitor $\mathrm{pH}$, glucose and VFA concentrations.

A fitting process was used to obtain kinetics coefficient values from the experimental data to calibrate the ISPAD model (Figure 2). The experimental data was corrected by subtracting the control value for $\mathrm{CO}_{2}, \mathrm{CH}_{4}, \mathrm{VFAs}$, and glucose. 


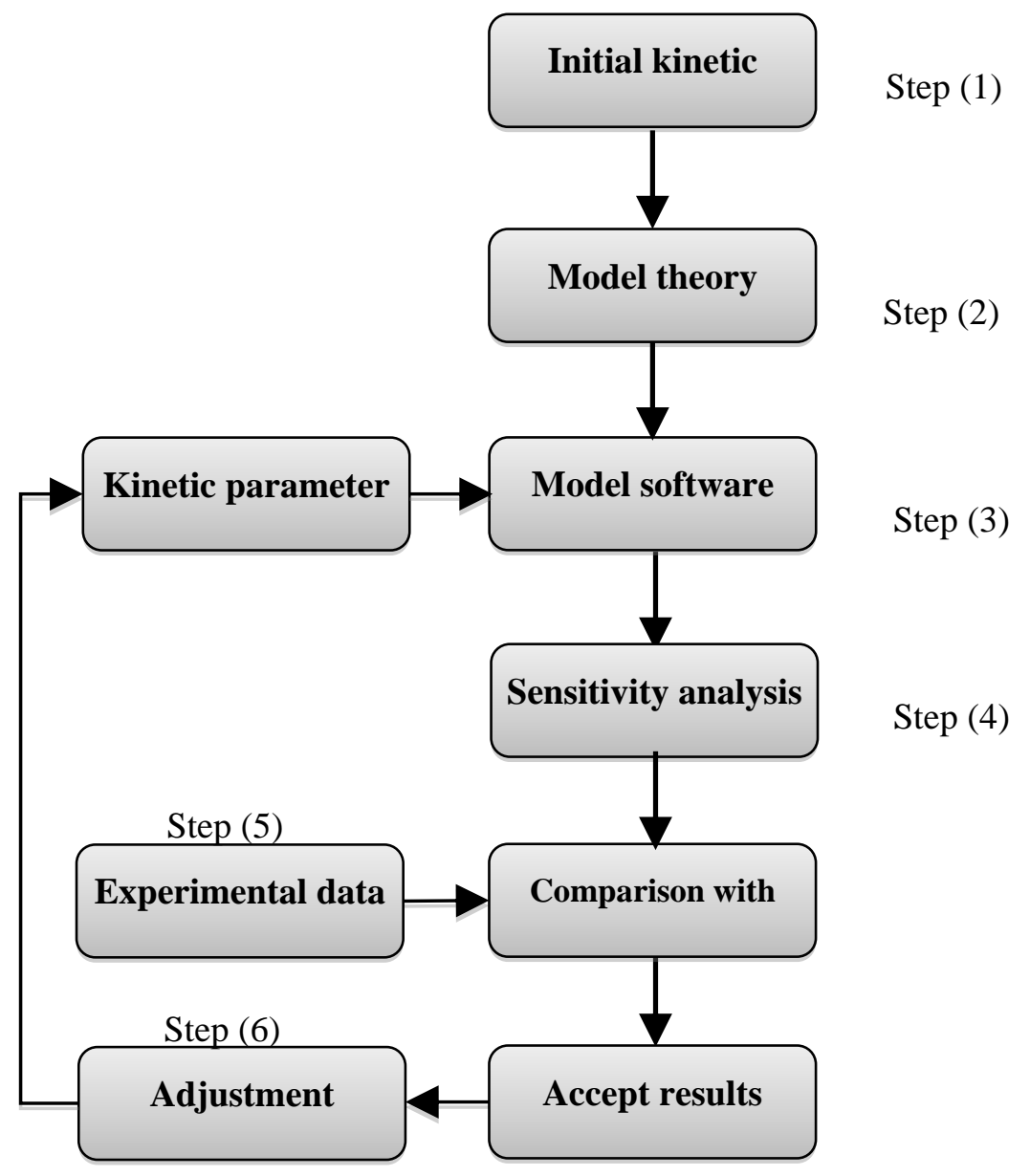

Figure 2. Steps in the modeling process

The fitting process was initiated at $35{ }^{\circ} \mathrm{C}$ using the values of $\mu_{\max }, K_{s}, Y$, and bacterial density $(X)$ determined by Madani-Hosseini et al. (Madani-Hosseini et al., 2014) and inhibition kinetic values based on Keshtkar et al. (2001) (step 1, Figure 2). The fitting process consisted of integrating the theoretical equations of the ISPAD model (step 2, Figure 2) into the software Matlab/Simulink (MathWorks, 2012a) (step 3, Figure 2). Furthermore, a batch system was reproduced in the Matlab/Simulink software to match the experimental batch tests. Then, an iterative loop consisting of steps 3, 4 and 6 (Figure 2) was started using the ISPAD model to obtain the best fitting kinetic parameters.

Once the kinetic coefficient and microbial population values were obtained for $35{ }^{\circ} \mathrm{C}$ conditions, curve fitting was extended to the 18 and $8{ }^{\circ} \mathrm{C}$ data. Microbial population values for $35{ }^{\circ} \mathrm{C}$ were presumed to be the same for the 18 and $4{ }^{\circ} \mathrm{C}$ curve fitting operations.

To find the coefficient of variation (C.V.) for the kinetics coefficients, the data from each individual quadruplet runs at $18{ }^{\circ} \mathrm{C}$ was fitted using the ISPAD model. The quadruplet runs were obtained from the duplicate fed glucose and the control fed no glucose. 


\subsection{Analytical Procedure}

The experimental inoculum was obtained in 2012 from a 7-year-old field ISPAD system treating swine manure in the Drummondville area of Eastern Canada. The ISPAD samples were analyzed according to standard methods (Eaton \& Franson, 2005) to establish: solids (TS, VS, TSS, VSS, FS and VDS) and $\mathrm{pH}$. To measure COD, commercial COD test kits for ultra-high rate COD were used (DR/4000, $\mathrm{HACH}$ Corp). Anions including $\mathrm{Cl}^{-}, \mathrm{NO}_{3}{ }^{2-}, \mathrm{NO}_{2}{ }^{-}$, $\mathrm{SO}_{4}{ }^{2-}$ and $\mathrm{PO}_{4}{ }^{3-}$ and the cation of $\mathrm{NH}_{4}{ }^{+}$were determined by $\mathrm{HACH}$ kit/high rate.

To monitor gas production from the batch tests, the biogas composition $\left(\mathrm{CH}_{4}\right.$, and $\left.\mathrm{CO}_{2}\right)$ was measured by injecting $2 \mathrm{ml}$ samples into a gas chromatograph (Varian, model 3800) equipped with TCD detector and CARBOXEN 1010 PLOT (capillary column) from SUPELCO,

$30 \mathrm{~mm} \times 0.53 \mathrm{~mm}$ column. The carrier gas was helium/argon. The column temperature was held at $50-100{ }^{\circ} \mathrm{C}$ for $5{ }^{\circ} \mathrm{C} / \mathrm{min}$. The injection flow was $5 \mathrm{ml} / \mathrm{min}$.

The liquid samples were analyzed for VFAs by HPLC (Beckman Coulter Inc, Gold system) where the HPLC spectra were analyzed using the Beckman Coulter Inc. software (32 Karat Software, Beckman Coulter Inc.). Before injection, samples were filtered using a syringe filter, PTFE (polytetrafluoroethylene), $25 \mathrm{~mm}$ diameter, $0.45 \mu \mathrm{m}$ to remove solids. The samples were injected into a polystyrene resin chromatography column $(30 \mathrm{~cm} \times 7.8 \mathrm{~mm}$ ID, SUPLECOGEL model C-610H, USA). The parameters were: mobile phase of $0.1 \%$ phosphoric acid, $100 \mu \mathrm{L}$ injection, UV detection wavelength of $210 \mathrm{~nm}$, and $0.5 \mathrm{ml} / \mathrm{min}$ flow rate at $30{ }^{0} \mathrm{C}$. The glucose concentration was measured by the colorimetric method (Lever, 1972).

\section{Results and Discussion}

\subsection{Inoculum Characterization}

The ISPAD inoculum is characterized in Table 4 along with fresh swine manure assumed to be diluted to give the same Fixed Solid (FS) level, because this component is not affected by AD. The ISPAD inoculum offers much lower TS and VS levels because of the loss of carbon during AD degradation (Susan Marguerite King, 2011). As for $\mathrm{NH}_{4}{ }^{+}-\mathrm{N}$ and $\mathrm{PO}_{4}{ }^{-3}$, their values are higher for the ISPAD inoculum because of $\mathrm{AD}$ degrading organic components releasing such elements. Mineral concentrations are similar, because these are soluble elements not affected by $\mathrm{AD}$, but rather by diet. The low concentrations of VFAs in the ISPAD inoculum, and the resulting increase in $\mathrm{pH}$, confirm that the process is well acclimated to operating conditions (O. R. Kotsyurbenko, 2005). Therefore, the 7-year old ISPAD content could be used as inoculum as it was considered to offer a fully functional microbial population (Wilkie, 2005). 
Table 4. Characteristics of experimental ISPAD inoculum and fresh swine manure

\begin{tabular}{|c|c|c|}
\hline Characteristic & ISPAD inoculum & Fresh swine manure $^{2}$ \\
\hline $\begin{array}{l}\text { Solids }(\mathrm{g} / \mathrm{L}) \\
\text { - Total } \\
\text { - Volatile } \\
\text { - Fixed } \\
\text { - Dissolved } \\
\text { - Suspended }\end{array}$ & $\begin{array}{l}14.03(0.50)^{1} \\
7.22(0.09) \\
6.81(0.50) \\
13.8(0.50) \\
0.23(0.07)\end{array}$ & $\begin{array}{l}30.0(1.44) \\
23.2(0.15) \\
6.8 \\
- \\
-\end{array}$ \\
\hline $\mathrm{pH}$ & $8.17(0.09)$ & 7.5 \\
\hline $\begin{array}{l}\text { Nitrogen }(\mathrm{g} / \mathrm{L}) \\
-\mathrm{TKN} \\
-\mathrm{NH}_{4}-\mathrm{N} \\
-\mathrm{NO}_{3}-\mathrm{N}\end{array}$ & $\begin{array}{l}1.89(0.25) \\
1.71(0.085) \\
0.013(0.001)\end{array}$ & $\begin{array}{l}1.40(0.56) \\
0.78(0.27) \\
-\end{array}$ \\
\hline $\begin{array}{l}\text { Phosphorous }(\mathrm{g} / \mathrm{L}) \\
- \text { Total } \\
-\mathrm{PO}_{4}^{-3}-\mathrm{P}\end{array}$ & $\begin{array}{l}- \\
0.53(0.011)\end{array}$ & $\begin{array}{l}0.50(0.27) \\
0.33\end{array}$ \\
\hline $\begin{array}{l}\text { Mineral }(\mathrm{g} / \mathrm{L}) \\
-\mathrm{Ca} \\
-\mathrm{K} \\
-\mathrm{Mg} \\
-\mathrm{Na}\end{array}$ & $\begin{array}{l}- \\
0.85(0.24) \\
- \\
0.34(0.29)\end{array}$ & $\begin{array}{l}0.90(0.49) \\
0.80(0.44) \\
0.18(0.09) \\
0.18(0.14)\end{array}$ \\
\hline $\begin{array}{l}\text { VFAs }(\mathrm{g} / \mathrm{L}) \\
\text { - Acetic } \\
\text { - Propionic } \\
\text { - Butyric }\end{array}$ & $\begin{array}{l}0.03(0.00) \\
0.00(0.00) \\
0.00(0.00) \\
\end{array}$ & $\begin{array}{l}- \\
- \\
-\end{array}$ \\
\hline $\mathrm{COD}(\mathrm{g} / \mathrm{L})$ & $5.95(0.45)$ & - \\
\hline $\begin{array}{l}{ }^{1} \text { Standard deviation } \\
{ }^{2}(\mathrm{ASABE}, 2000)\end{array}$ & brackets & \\
\hline
\end{tabular}

\subsection{Estimated Kinetic Parameters and Conversion Factors}

Table 5 compared the kinetic coefficients obtained in this study using 2012 ISPAD inoculum, to that of a previous study (Madani-Hosseini et al., 2014) using 2009 ISPAD inoculum and that of another research conducted at $6{ }^{\circ} \mathrm{C}$ but for cattle manure. Model fitting of the AD experimental data was used to establish the 2012 ISPAD kinetics values.

For the ISPAD system, comparing the 2012 to the 2009 kinetic values provides an indicator of acclimation for the microbial communities. Kinetic values obtained at $35{ }^{\circ} \mathrm{C}$ depend on the freshness of the inoculum because the experimental ISPAD system was regularly fed with fresh manure containing mesophilic populations which become active for a certain amount of time, during the initial stages of AD (Susan Marguerite King, 2011). The significant differences will therefore concentrate on results obtained at 4 and $18{ }^{\circ} \mathrm{C}$ : 
1) At $4{ }^{\circ} \mathrm{C}$, higher maximum growth rates for the acidogens, butyrate degrading acetogens, and acetoclastic methanogens, but a drop for the propionate degrading acetogens; this observation confirms that lower temperatures favour butyrate rather than propionate degradation;

2) At $18{ }^{\circ} \mathrm{C}$, higher maximum growth rates for the acidogens and butyrate degraders, but no change for the propionate degrading acetogens and the acetoclastic methanogens;

3) At $4{ }^{\circ} \mathrm{C}$, a higher substrate affinity for the propionate and butyrate degrading acetogens, and the acetoclastic methanogens, but a lower affinity for the acidogens;

4) At $18{ }^{\circ} \mathrm{C}$, a higher substrate affinity for the buryrate degrading acetogens, but no change for all other microbial groups;

5) a higher microbial growth rate for the acidogens and acetoclastic methanogens.

Accordingly, the acclimation of the ISPAD microbial population has been evolving over time, from 2009 to 2012.

Comparing the 2012 ISPAD kinetics to that of Vavilin (V. A. Vavilin et al., 1998):

1) the maximum growth rate of the ISPAD acidogens is increasing towards that of the Vavilin value, but the substrate affinity is becoming less sensitive with time as compared to that of Vavilin;

2) the maximum growth rate of the ISPAD propionate and butyrate degrading acetogens is within the range of that of Vavilin, but offers a much lower affinity for the substrate;

3) the maximum growth rate and substrate affinity for the ISPAD homoacetogens is much lower than that of Vavilin;

4) the maximum growth rate and substrate affinity for the ISPAD homoacetogens is much higher than that of Vavilin.

A comparison of the Vavilin kinetics indicate that the ISPAD microbial populations can further acclimate to psychrophilic conditions.

The coefficients of variation (C.V.) were calculated for the batch test conducted at $18{ }^{\circ} \mathrm{C}$ (Table 5), to check the level of result variability. The maximum growth rate, $\mu_{\max }$, of the acidogens and hydrogenotrophic methanogens showed the highest C.V. of 6 to 20\%, while all other kinetic parameters showed a C.V. of under 5\%. As for other kinetic parameters, variation of $K_{s}$ values with temperature was larger than the C.V., indicating that temperature had a significant effect.

Table 5. Estimated ISPAD kinetic values at 2009 and 2012

\begin{tabular}{|c|c|c|c|c|c|c|c|c|c|}
\hline \multirow{3}{*}{ Process } & \multirow{3}{*}{ Parameter } & \multirow{3}{*}{ Units } & \multicolumn{6}{|c|}{ Value } & \multirow{3}{*}{$6{ }^{0} \mathrm{C}^{3}$} \\
\hline & & & $8{ }^{0} \mathrm{C}$ & $4{ }^{0} \mathrm{C}$ & \multicolumn{2}{|c|}{$18^{0} \mathrm{C}$} & \multicolumn{2}{|c|}{$35^{0} \mathrm{C}$} & \\
\hline & & & $2009^{1}$ & 2012 & 2009 & 2012 & 2009 & 2012 & \\
\hline 1. Acidogenesis & $\mu_{\max A}$ & $1 /$ day & 0.64 & 1.10 & 2.9 & $\begin{array}{l}3.70 \\
(0.066)^{2}\end{array}$ & 6.4 & 7.90 & 2 \\
\hline
\end{tabular}




\begin{tabular}{|c|c|c|c|c|c|c|c|c|c|}
\hline & $K_{\text {sglu }}$ & $m g / L$ & 219 & 321 & 167 & $\begin{array}{l}140 \\
(0.11)\end{array}$ & 140 & 35 & 113.4 \\
\hline & $Y_{A}$ & $\mathrm{mg} / \mathrm{mg}$ & 0.123 & 0.110 & 0.123 & $\begin{array}{l}0.110 \\
(0.16)\end{array}$ & 0.123 & 0.030 & 0.2 \\
\hline & $X_{A}$ & $m g / L$ & 7.54 & 2.2 & 7.54 & $\begin{array}{l}22 \\
(0.05)\end{array}$ & 7.54 & 2.2 & - \\
\hline \multirow{5}{*}{$\begin{array}{l}2 . \quad \text { Propionate } \\
\text { degrading } \\
\text { acetogenesis }\end{array}$} & $\mu_{\operatorname{maxAP}}$ & $1 /$ day & 0.11 & 0.01 & 0.06 & $\begin{array}{l}0.05 \\
(0.12)\end{array}$ & 0.12 & 0.03 & $0.07-0.08$ \\
\hline & $K_{s p r}$ & $m g / L$ & 392 & 189 & 163 & $\begin{array}{l}111 \\
(0.08)\end{array}$ & 100 & 21 & 19.98 \\
\hline & $Y_{A P}$ & $\mathrm{mg} / \mathrm{mg}$ & 0.053 & 0.01 & 0.053 & $\begin{array}{l}0.03 \\
(0.01)\end{array}$ & 0.053 & 0.090 & 0.05 \\
\hline & $X_{A P}$ & $m g / L$ & 18.32 & 59.0 & 18.32 & $\begin{array}{l}59.0 \\
(0.00) \\
\end{array}$ & 18.32 & 59.0 & - \\
\hline & $K_{i p r}$ & $m g / L$ & - & 960 & - & $\begin{array}{l}960 \\
(0.00) \\
\end{array}$ & - & 960 & - \\
\hline \multirow{5}{*}{$\begin{array}{l}3 . \quad \text { Butyrate } \\
\text { degrading } \\
\text { acetogenesis }\end{array}$} & $\mu_{\max A B}$ & $1 /$ day & 0.023 & 0.14 & 0.22 & $\begin{array}{l}0.9 \\
(0.00)\end{array}$ & 0.23 & 0.08 & $0.09-0.13$ \\
\hline & $K_{s b u t}$ & $m g / L$ & 411 & 213 & 450 & $\begin{array}{l}124 \\
(0.00)\end{array}$ & 450 & 150 & 20.24 \\
\hline & $Y_{A B}$ & $\mathrm{mg} / \mathrm{mg}$ & 0.034 & 0.020 & 0.034 & $\begin{array}{l}0.008 \\
(0.00) \\
\end{array}$ & 0.034 & 0.026 & $0.08-0.1$ \\
\hline & $X_{A B}$ & $m g / L$ & 85.96 & 15.50 & 85.96 & $\begin{array}{l}15.50 \\
(0.00) \\
\end{array}$ & 85.96 & 15.50 & - \\
\hline & $K_{i b u t}$ & $m g / L$ & - & 720 & - & $\begin{array}{l}720 \\
(0.00)\end{array}$ & - & 720 & - \\
\hline \multirow{4}{*}{$\begin{array}{l}4 . \\
\text { Homoacetogenesis }\end{array}$} & $\mu_{\operatorname{maxHom}}$ & $1 /$ day & - & 0.44 & - & $\begin{array}{l}0.73 \\
(0.02)\end{array}$ & - & - & 1 \\
\hline & $K_{S C O}$ & $m g / L$ & - & 300 & - & $\begin{array}{l}160 \\
(0.04)\end{array}$ & - & - & 10.56 \\
\hline & $Y_{\text {Hom }}$ & $\mathrm{mg} / \mathrm{mg}$ & - & 0.042 & - & $\begin{array}{l}0.058 \\
(0.1)\end{array}$ & - & - & 0.05 \\
\hline & $X_{\text {Hom }}$ & $m g / L$ & - & 65.0 & - & $\begin{array}{l}65 \\
(0.05)\end{array}$ & - & - & - \\
\hline \multirow{4}{*}{$\begin{array}{l}\text { 5. Acetoclastic } \\
\text { Methanogenesis }\end{array}$} & $\mu_{\max M A}$ & $1 /$ day & 0.045 & 0.19 & 0.2 & $\begin{array}{l}0.23 \\
(0.11)\end{array}$ & 0.4 & 0.60 & $0.008-0.022$ \\
\hline & $K_{\text {sac }}$ & $m g / L$ & 533 & 210 & 213 & $\begin{array}{l}351 \\
(0.02)\end{array}$ & 193 & 113 & 348 \\
\hline & $Y_{M A}$ & $\mathrm{mg} / \mathrm{mg}$ & 0.019 & 0.010 & 0.019 & $\begin{array}{l}0.038 \\
(0.06)\end{array}$ & 0.019 & 0.060 & 0.01 \\
\hline & $X_{M A}$ & $m g / L$ & 23.59 & 11.50 & 23.59 & $\begin{array}{l}11.50 \\
(0.08) \\
\end{array}$ & 23.59 & 11.50 & - \\
\hline
\end{tabular}




\begin{tabular}{|c|c|c|c|c|c|c|c|c|c|}
\hline & $K_{\text {iam }}$ & $m g / L$ & - & 260 & - & $\begin{array}{l}260 \\
(0.00)\end{array}$ & - & 260 & \\
\hline \multirow{4}{*}{$\begin{array}{l}6 . \\
\text { Hydrogenotrophic } \\
\text { Methanogenesis }\end{array}$} & $\mu_{\max M H}$ & $1 /$ day & - & 0.1 & - & $\begin{array}{l}0.23 \\
(0.20)\end{array}$ & - & 0.32 & 0.8 \\
\hline & $\mathrm{K}_{\mathrm{sCO}}$ & $m g / L$ & - & 170.00 & - & $\begin{array}{l}32.5 \\
(0.1)\end{array}$ & - & 29.00 & 10.56 \\
\hline & $Y_{M H}$ & $\mathrm{mg} / \mathrm{mg}$ & - & 0.015 & - & $\begin{array}{l}0.005 \\
(0.28)\end{array}$ & - & 0.03 & 0.04 \\
\hline & $X_{M H}$ & $m g / L$ & - & 45.0 & - & $\begin{array}{l}45.0 \\
(0.08)\end{array}$ & - & 45.0 & - \\
\hline
\end{tabular}

Table 6 presents the optimized conversion factors at 4,18 , and $35^{\circ} \mathrm{C}$. The main carbon flow in the acidogenesis step happened between glucose and acetate at a higher temperature, in agreement with Husain (1998). However, at $4{ }^{\circ} \mathrm{C}$, the carbon flow in acidogenesis occurred between glucose and $\mathrm{CO}_{2}$. The V. A. Vavilin et al. (1998) model calibration indicated that most of the glucose was converted to $\mathrm{CO}_{2}$ under psychrophilic conditions. At higher temperatures, higher levels of propionate rather than butyrate resulted from glucose degradation. When temperature dropped from 35 to $4{ }^{\circ} \mathrm{C}$, glucose conversion to butyrate was almost 2.5 times higher than that of propionate. Temperature also affects propionate conversion, where most of the propionate is converted to acetate at a low temperature of $4{ }^{\circ} \mathrm{C}$ and to $\mathrm{CO}_{2}$ at higher temperatures of 18 and $35{ }^{\circ} \mathrm{C}$. For methanogenesis at higher temperatures, most of the $\mathrm{CH}_{4}$ production came from hydrogenotrophic methanogenesis. However, at lower temperatures, $\mathrm{CH}_{4}$ was mostly produced by the acetoclastics methanogens. Oleg R Kotsyurbenko, Glagolev, Nozhevnikova, and Conrad (2001) showed that under psychrophilic conditions $\left(<15{ }^{\circ} \mathrm{C}\right)$, the hydrogenotrophic methanogen activity was very low. Homoacetogenesis is mainly responsible for $\mathrm{H}_{2}$ consumption and under such conditions, $\mathrm{CH}_{4}$ formation through acetoclastic methanogens becomes dominant. Homoacetogenesis under psychrophilic temperatures can be responsible for $95 \%$ of the total $\mathrm{CH}_{4}$ production $(\mathrm{O}$. R. Kotsyurbenko, 2005).

Table 6. Conversion factors used in the model to achieve a carbon mass balance, where Figure 1 illustrates the process associated with each factor.

\begin{tabular}{|l|l|l|l|}
\hline \multirow{2}{*}{ Symbol } & \multicolumn{3}{|c|}{ Conversion factor $(\%)$} \\
\cline { 2 - 4 } & $4{ }^{\circ} \mathrm{C}$ & $18{ }^{\circ} \mathrm{C}$ & $35^{\circ} \mathrm{C}$ \\
\hline$a$ & 20 & 47 & 30 \\
\hline$b$ & 25 & 23 & 13 \\
\hline$c$ & 10 & 10 & 27 \\
\hline$d$ & 40 & 20 & 30 \\
\hline$e$ & 67 & 5 & 20 \\
\hline$f$ & 33 & 95 & 80 \\
\hline$g$ & 100 & 100 & 100 \\
\hline$i$ & 67 & 67 & 5 \\
\hline$j$ & 5 & 10 & 50 \\
\hline
\end{tabular}




\subsection{Sensitivity Analysis}

To reduce the number of parameters requiring calibration, a sensitivity analysis was conducted to determine which independent variable impacts a specific dependent variable under a given set of assumptions. Local and global sensitivity analysis (Bernard, Hadj Sadok, Dochain, Genovesi, \& Steyer, 2001; Noykova \& Gyllenberg, 2000; Tartakovsky et al., 2008; V. Vavilin, Rytov, Pavlostathis, Jokela, \& Rintala, 2003) evaluate respectively: linear perturbations for the output for a specific set of parameters, and; the sensitivity for a broader spectrum of input parameters in nonlinear models. Because AD models represent a complex usually nonlinear system, the global sensitivity method is preferred.

Sensitivity was quantified in terms of variation in measurable process under the perturbation of model parameters in their neighbourhood domain. The variance-based method was chosen for the global sensitivity analysis, correlating the variance of inputs and outputs for steady state simulations. The variance in the parameters will lead to a variance in output, and an important parameter will have a bigger impact on the output variance than a parameter for which the model is less sensitive.

Simulations using Keshtkar et al. (2001) inhibition kinetic values showed less than 50\% discrepancies between the experimental results and the model predictions. Thus, the parameters in the Keshtkar et al. (2001) model were kept constant. However, all other kinetic parameters of $\mu_{\max }, K_{s}, Y$, and $X$ were optimized because of their high sensitivity range.

\subsection{Model Prediction}

To analyse the ability of the model to simulate the ISPAD system, the correlation coefficients (R) were calculated. The results showed that the $R$ values were in the range of 0.6 to 0.98 , indicating a reasonable prediction. A correlation greater than 0.8 is generally described as strong, whereas a correlation under 0.5 is generally described as weak. The model prediction for $\mathrm{CO}_{2}, \mathrm{CH}_{4}$, glucose, VFAs, and $\mathrm{pH}$ are described in detail as follows.

\subsubsection{Simulation of $\mathrm{CH}_{4}$ and $\mathrm{CO}_{2}$}

Figure 3 shows measured and simulated results for $\mathrm{CH}_{4}$ and $\mathrm{CO}_{2}$ production per glucose consumption, at 4,18 and $35{ }^{\circ} \mathrm{C}$ after model calibration. Overall, model prediction at 18 and $4{ }^{\circ} \mathrm{C}$ was better than at $35{ }^{\circ} \mathrm{C}$ which increased with time.

The duration of the lag phase increased as temperature dropped, with $4{ }^{\circ} \mathrm{C}$ showing the longest duration. At $4{ }^{\circ} \mathrm{C}, \mathrm{CH}_{4}$ conversion rate, about $0.6 \mathrm{CH}_{4}(\mathrm{mg}-\mathrm{C}) /$ glucose $(\mathrm{mg}-\mathrm{C})$, was less than that at 18 and $35{ }^{\circ} \mathrm{C}$ at $0.8 \mathrm{CH}_{4}(\mathrm{mg}-\mathrm{C}) / \mathrm{Glucose}(\mathrm{mg}-\mathrm{C})$ after 6 and 10 days of incubation, respectively. Production of $\mathrm{CH}_{4}$ at $4{ }^{\circ} \mathrm{C}$ started to slowly increase after 10 days of incubation and reached $0.6 \mathrm{CH}_{4}(\mathrm{mg}-\mathrm{C}) /$ glucose $(\mathrm{mg}-\mathrm{C})$ after 22 days. Production of $\mathrm{CH}_{4}$ as per glucose consumption at a 6 day incubation for $35^{\circ} \mathrm{C}$ was 1.7 and 32.4 times higher than at 18 , and $4{ }^{\circ} \mathrm{C}$, respectively. 


\section{Macrothink}

The model predicted a $\mathrm{CO}_{2}$ production at $35{ }^{\circ} \mathrm{C}$ sharply increasing at the beginning of the experiment, compared to a smooth increase at $4{ }^{\circ} \mathrm{C}$. The model $\mathrm{CO}_{2}$ prediction ability at $4{ }^{\circ} \mathrm{C}$ was better than those of 35 and $18{ }^{\circ} \mathrm{C}$. The biogas $\mathrm{CO}_{2}$ fraction increased when temperature decreased to $4{ }^{\circ} \mathrm{C}$. This behaviour could be due to the methanogens lag phase at lower temperatures.
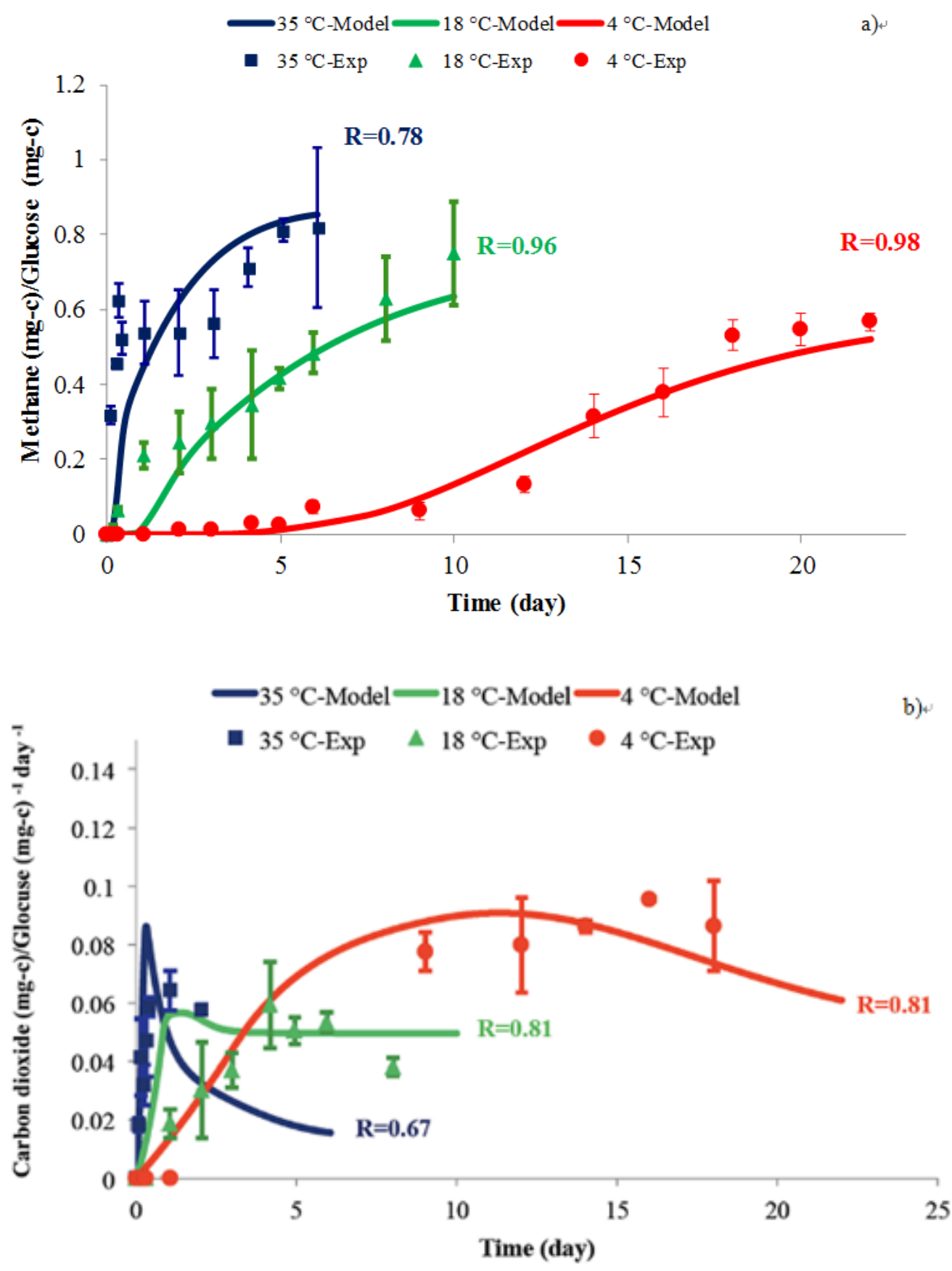

Figure 3. Simulation of biogas production, a) for $\mathrm{CH}_{4}$ and b) for $\mathrm{CO}_{2}$, from glucose degraded at 35,18 , and $4{ }^{\circ} \mathrm{C}$ by the 2012 ISPAD inoculum. Experimental data, point; model prediction, line. Note: Data points represent the average of two replicates and error bars represent $+/$ - one standard deviation. 


\section{Macrothink

\subsubsection{Simulation of glucose and VFAs}

Glucose degradation by the ISPAD inoculum at 35,18 and $4{ }^{\circ} \mathrm{C}$ is illustrated by Figure 4 . The model accurately predicted glucose consumption at all temperatures with the curve stretched in time as temperature drops, showing that acidogens consumed glucose faster at higher temperatures. Complete glucose consumption at $4{ }^{\circ} \mathrm{C}$ required over 22 days as compared to 1 and 3 days at 18 and $35^{\circ} \mathrm{C}$.

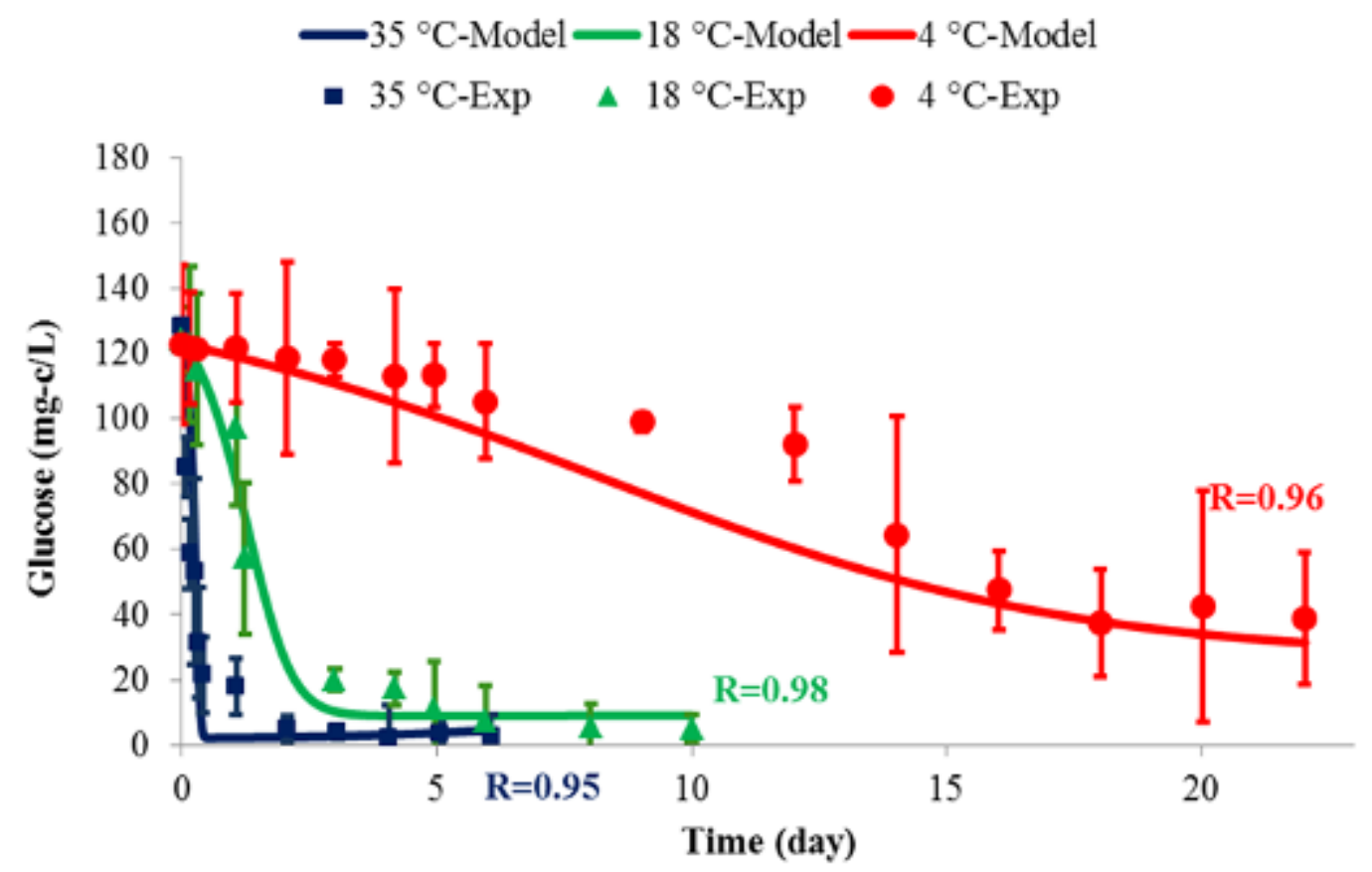

Figure 4. Simulation of glucose degradation at 35,18 , and $4{ }^{\circ} \mathrm{C}$, with the 2012 ISPAD inoculum. Experimental data, point; model prediction, line. Note: Data points represent the average of two replicates and error bars represent +/- one standard deviation.

At all temperatures, acetate was the major VFA produced (Figure 5) (Wang, Kuninobu, Ogawa, \& Kato, 1999). At 35 and $18{ }^{\circ} \mathrm{C}$, acetate production showed the steepest slope at the beginning of the experiment, as compared to a slow increase at $4{ }^{\circ} \mathrm{C}$, as a result of a lag phase. While the temperature affected the acetate and propionate concentration, it had no significant effect on butyrate concentration. While butyrate was consumed by methanogens, propionate persisted in the reactor, specifically at $4{ }^{\circ} \mathrm{C}$. Low temperatures of 3 to $9{ }^{\circ} \mathrm{C}$ are known to favour the degradation of butyrate over propionate (Nozhevnikova et al., 2000). Furthermore, $\mathrm{CH}_{4}$ production from propionate is slower than that from butyrate and acetate, because of its thermodynamically unfavourable AD process (Gijzen, Zwart, Verhagen, \& Vogels, 1988). 

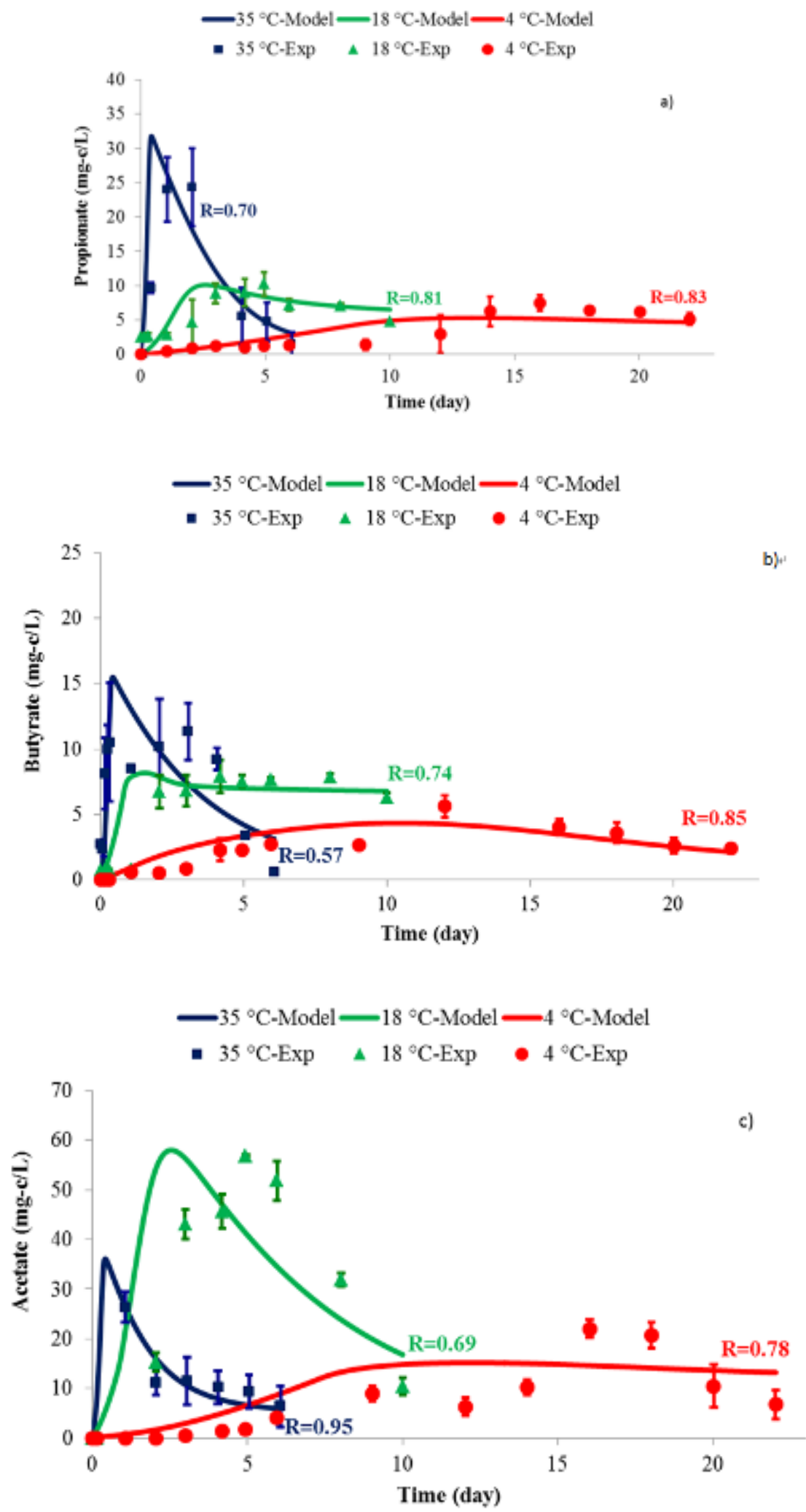

Figure 5. Simulation of VFAs production from glucose degradation at 35,18 , and $4{ }^{\circ} \mathrm{C}$, with the 2012 ISPAD inoculum. Experimental data, point; model prediction, line. Note: Data points represent the average of two replicates and error bars represent $+/$ - one standard deviation. 


\subsubsection{Simulation of $\mathrm{pH}$}

The optimized dissociation constants for the main active acids and bases, $K_{a}$, for ISPAD content at all 3 temperatures are presented in Table 4 . At $35{ }^{\circ} \mathrm{C}$, the $K_{a}$ fitting process produced a major change in the second dissociation constant for carbonic acid, and a slight change in the dissociation constant for propionic and butyric acid. Values at $35{ }^{\circ} \mathrm{C}$ were adjusted to 18 and $4{ }^{\circ} \mathrm{C}$ using Eq. 4-21.

Figure 6 shows the fitting of the experimental data and model prediction for $\mathrm{pH}$ at all three temperatures. The $35{ }^{\circ} \mathrm{C}$ experimental results showed a $\mathrm{pH}$ dropping from 8.1 to 7.5 during the first day, to start climbing thereafter. At $18{ }^{\circ} \mathrm{C}$, the $\mathrm{pH}$ dropped from 8.0 to 7.7 on day 2, to remain constant thereafter, whereas at $4{ }^{\circ} \mathrm{C}$, the $\mathrm{pH}$ remained at 8.0 during the full experimental period.

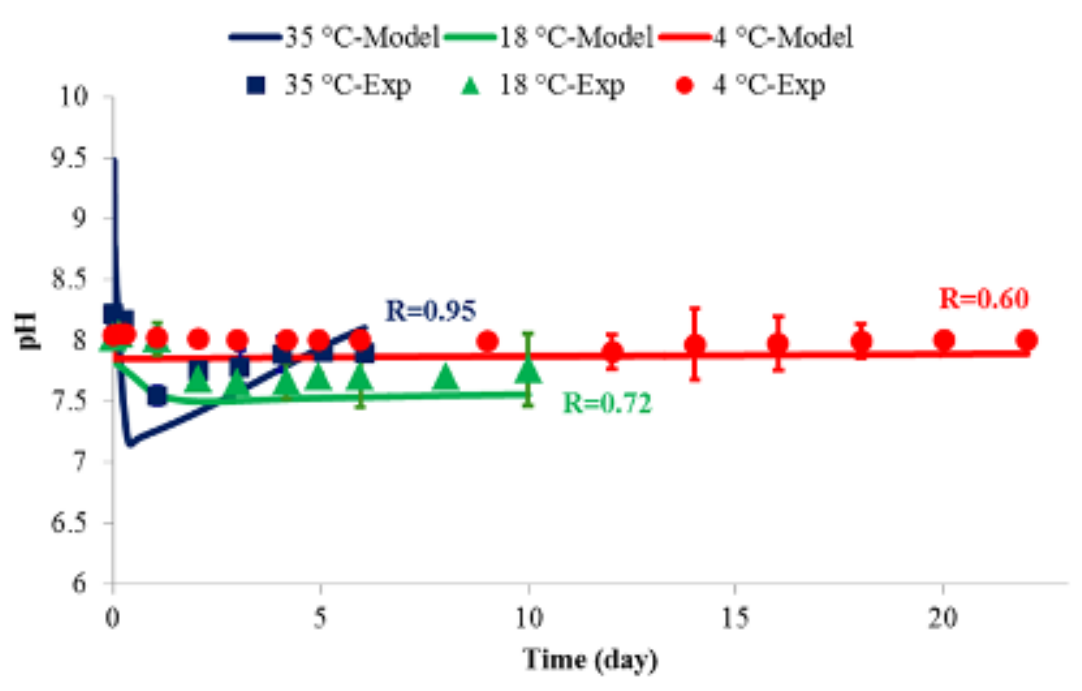

Figure 6. Simulation of $\mathrm{pH}$ from glucose degradation at 35,18 , and $4{ }^{\circ} \mathrm{C}$, with the 2012

ISPAD inoculum. Experimental data, point; model prediction, line. Note: Data points represent the average of two replicates and error bars represent $+/$ - one standard deviation.

The model was able to predict the $\mathrm{pH}$ regime with an $\mathrm{R}$ value of $0.95,0.72$ and 0.6 at 35,18 and $4{ }^{\circ} \mathrm{C}$, respectively. Nevertheless, at $18{ }^{\circ} \mathrm{C}$, the model predicted a $\mathrm{pH}$ of 7.5 compared to 7.7 for the experimental data, and at $4{ }^{\circ} \mathrm{C}$, the model predicted a $\mathrm{pH}$ of 7.9 compared to 8.0 for the experimental data. Literature $\mathrm{AD}$ models were also found to predict system $\mathrm{pH}$ with similar accuracy. For example, the AD model proposed by V. A. Vavilin et al. (1998) and the ADMI model applied to olive mill wastewaters (Fezzani \& Cheikh, 2008) predicted the pH regime within a $\mathrm{pH}$ unit variation of 1.0 and 0.5 , respectively.

\section{Conclusions}

An alternative to the conventional anaerobic digestion reactor, In-Storage-Psychrophilic-Anaerobic-Digestion (ISPAD) is a system offering an affordable process to units producing a limited amount of organic wastewaters which must be stored for 
at least 100 days. Nevertheless, ISPAD is a sequentially fed batch process relying on acclimated microbial groups which have not been fully characterized. The objective of the research was to develop the knowledge and a model capable of optimizing the operation of ISPAD by predicting its behaviour under operating conditions. To do so, the research evaluated ISPAD kinetic values and developed an anaerobic digestion (AD) model capable of predicting the process. Also, by comparing 2009 and 2012 fitted kinetic values, the research work was able to verify if the microbial communities were still acclimating to the psychrophilic conditions imposed by the ISPAD system. The mathematical ISPAD model developed is able to predict substrate consumption, VFA levels, biogas generation and $\mathrm{pH}$ evolution. The model did not include hydrolysis, as this step is quite complex and requires research as extensive as the present predicting methane production and $\mathrm{pH}$ regime from glucose degradation.

The model was developed from that of Keshtkar et al. (2001), by adding functions specific to low temperature $\mathrm{AD}$ such as determining the activity of the two main groups of methanogens, acetoclastic and hydrogenotrophic, and; including a temperature function for the maximum microbial growth rate, $\mu_{\max }$, and the acid/base dissociation constant $\left(K_{a}\right)$. The fitted kinetic values obtained from the developed model showed that the microbial communities were still acclimating to the low operating temperatures. Furthermore, the ISPAD model was able to predict glucose concentration with an $\mathrm{R}$ value of 0.95 to 0.98 , methane production with an $\mathrm{R}$ value of 0.78 to $0.98, \mathrm{pH}$ regime with an $\mathrm{R}$ value of 0.60 to 0.95 and acetate with an $\mathrm{R}$ value of 0.69 to 0.95 . Full testing of the ISPAD model still requires validation.

\section{Acknowledgement}

The authors acknowledge the financial contribution of Geomembrane Technology Inc. (Fredericton, New Brunswick, Canada) and the Natural Science and Engineering Research Council of Canada (NSERC) and Concordia University.

\section{References}

Angelidaki, I., Ellegaard, L., \& Ahring, B. K. (1993). A Mathematical Model for Dynamic Simulation of Anaerobic Digestion of Complex Substrates: Focusing on Ammonia Inhibition. Biotechnology and Bioengineering, 42(2), 159-166.

ASABE. (2000). Standards Manual. St Joseph, Michigan, USA. : American Society of Agricultural and Biological Engineering.

Batstone, D. J., Keller, J., Angelidaki, I., Kalyuzhny, S. V., Pavlostathis, S. G., Rozzi, A., Vavilin, V. A. (2002). Anaerobic Digestion Model No. 1 (ADM1): IWA Publishing.

Bernard, O., Hadj-Sadok, Z., Dochain, D., Genovesi, A., \& Steyer, J. P. (2001). Dynamical Model Development and Parameter Identification for an Anaerobic Wastewater Treatment Process. Biotechnology and Bioengineering, 75(4), 424-438.

Biogas. (2011). Using biogas. The Official Information Portal on Anaerobic Digestion. 
Cakir, F., \& Stenstrom, M. (2005). Greenhouse gas production: a comparison between aerobic and anaerobic wastewater treatment technology. Water Research, 39(17), 4197-4203.

Chen, Y., Cheng, J. J., \& Creamer, K. S. (2008). Inhibition of anaerobic digestion process: A review. Bioresource technology, 99(10), 4044-4064. Retrieved from http://www.sciencedirect.com/science/article/pii/S0960852407001563

Dean, J. A. (1992). Lange's handbook of chemistry. McGraw Hill, New York, fourteenth ed. Retrieved from http://www.osti.gov/energycitations/product.biblio.jsp?osti_id=5776187

Donoso-Bravo, A., Mailier, J., Martin, C., Rodríguez, J., Aceves-Lara, C. A., \& Wouwer, A. V. (2011). Model Selection, Identification and Validation in Anaerobic Digestion: A Review. Water Research, 45(17), 5347-5364.

Eaton, A. D., \& Franson, M. A. H. (2005). Standard Methods for the Examination of Water \& Wastewater. Washington, D.C.: American Public Health Association.

Fezzani, B., \& Cheikh, R. B. (2008). Implementation of IWA anaerobic digestion model No. 1 (ADM1) for simulating the thermophilic anaerobic co-digestion of olive mill wastewater with olive mill solid waste in a semi-continuous tubular digester. Chemical Engineering Journal, 141(1), 75-88.

Giard, (2011). Biogas Production Regime for In-Storage-Psychrophilic-Anaerobic-Digestion. McGill University.

Gijzen, H. J., Zwart, K. B., Verhagen, F. J. M., \& Vogels, G. P. (1988). High - Rate Two Phase Process for the Anaerobic Degradation of Cellulose, Employing Rumen Microorganisms for an Efficient Acidogenesis. Biotechnology and Bioengineering, 31(5), 418-425.

Hill, D. T. (1982). A comprehensive dynamic model for animal waste methanogenesis. Transactions of the ASAE, 25(5), 1374-1380.

Hill, D. T., \& Barth, C. L. (1977). A Dynamic Model for Simulation of Animal Waste Digestion. Journal (Water Pollution Control Federation), 2129-2143.

Hill, D. T., Taylor, S. E., \& Grift, T. E. (2001). Simulation of low temperature anaerobic digestion of dairy and swine manure. Bioresource Technology, 78(2), 127-131.

Husain, A. (1998). Mathematical Models of the Kinetics of Anaerobic Digestion--A Selected Review. Biomass and Bioenergy, 14(5-6), 561-571.

Kapdi, S., Vijay, V., Rajesh, S., \& Prasad, R. (2005). Biogas scrubbing, compression and storage: perspective and prospectus in Indian context. Renewable energy, 30(8), 1195-1202.

Keshtkar, A., Ghaforian, H., Abolhamd, G., \& Meyssami, B. (2001). Dynamic Simulation of Cyclic Batch Anaerobic Digestion of Cattle Manure. Bioresource Technology, 80(1), 9-17.

King, S., Schwalb, M., Giard, D., Whalen, J., \& Barrington, S. (2012). Effect of ISPAD Anaerobic Digestion on Ammonia Volatilization from Soil Applied Swine Manure. Applied 
and Environmental Soil Science, 2012, 1-8.

King, S. M. (2011). In-Storage Psychrophilic Anaerobic Digestion of Swine Manure. McGill University.

King, S. M., Barrington, S., \& Guiot, S. R. (2011). In-Storage Psychrophilic Anaerobic Digestion of Swine Manure: Acclimation of the Microbial Community. Biomass and Bioenergy, 35(8), 3719-3726.

Kotsyurbenko, O. R. (2005). Trophic Interactions in the Methanogenic Microbial Community of Low - Temperature Terrestrial Ecosystems. FEMS Microbiology Ecology, 53(1), 3-13.

Kotsyurbenko, O. R., Glagolev, M. V., Nozhevnikova, A. N., \& Conrad, R. (2001). Competition between homoacetogenic bacteria and methanogenic archaea for hydrogen at low temperature. FEMS Microbiology Ecology, 38(2-3), 153-159.

Lever, M. (1972). A New Reaction for Colorimetric Determination of Carbohydrates. Analytical Biochemistry, 47(1), 273-279.

Liu, M., Giard, D., \& Barrington, S. (2013). Ammonium Dissociation for Swine and Dairy Cattle Manures. Journal of Environmental Protection, 4, 6.

Loehr, R. (1984). Polution control for agriculture (Second edition ed.). London: Academic Press Inc.

Madani-Hosseini, M., Barrington, S., \& Mulligan, C. (2014). Microbial Kinetic for In-Storage-Psychrophilic Anaerobic Digestion (ISPAD). Journal of Environmental Management, 146, 59-68.

Massé, D. I., \& Droste, R. (2000). Comprehensive model of anaerobic digestion of swine manure slurry in a sequencing batch reactor. Water Research, 34(12), 3087-3106.

Nohra, J. A., Barrington, S., Frigon, J. C., \& Guiot, S. R. (2003). In Storage Psychrophilic Anaerobic Digestion of Swine Slurry. Resources, Conservation and Recycling, 38(1), 23-37.

Noykova, N. A., \& Gyllenberg, M. (2000). Sensitivity Analysis and Parameter Estimation in a Model of Anaerobic Wastewater Treatment Processes with Substrate Inhibition. Bioprocess Engineering, 23(4), 343-349.

Nozhevnikova, A., Rebak, S., Kotsyurbenko, O., Parshina, S., Holliger, C., \& Lettinga, G. (2000). Anaerobic Production and Degradation of Volatile Fatty Acids in Low Temperature Environments. Water Science \& Technology, 41(12), 39-46.

Tartakovsky, B., Mu, S., Zeng, Y., Lou, S., Guiot, S., \& Wu, P. (2008). Anaerobic Digestion Model No. 1-Based Distributed Parameter Model of an Anaerobic Reactor: II. Model Validation. Bioresource Technology, 99(9), 3676-3684.

Vavilin, V., Rytov, S., Pavlostathis, S., Jokela, J., \& Rintala, J. (2003). A Distributed Model of Solid Waste Anaerobic Digestion: Sensitivity Analysis. Water Science \& Technology, 48(4), 147-154. 


\section{Macrothink}

Environmental Management and Sustainable Development

ISSN 2164-7682 2015, Vol. 4, No. 2

Vavilin, V. A., Lokshina, L. Y., Rytov, S. V., Kotsyurbenko, O. R., \& Nozhevnikova, A. N. (1998). Modelling Low-Temperature Methane Production from Cattle Manure by an Acclimated Microbial Community. Bioresource Technology, 63(2), 159-171.

Wang, Q., Kuninobu, M., Ogawa, H. I., \& Kato, Y. (1999). Degradation of volatile fatty acids in highly efficient anaerobic digestion. Biomass Bioenergy, 16(6), 407-416.

Wilkie, A. C. (2005). Anaerobic digestion of dairy manure: Design and process considerations. Dairy Manure Management: Treatment, Handling, and Community Relations, 301,312 .

\section{Copyright Disclaimer}

Copyright for this article is retained by the author(s), with first publication rights granted to the journal.

This is an open-access article distributed under the terms and conditions of the Creative Commons Attribution license (http://creativecommons.org/licenses/by/3.0/). 